University of Nebraska - Lincoln

DigitalCommons@University of Nebraska - Lincoln

USDA National Wildlife Research Center - Staff Publications
U.S. Department of Agriculture: Animal and Plant Health Inspection Service

June 2007

\title{
Caffeine Formulation for Avian Repellency
}

Scott J. Werner

USDA-APHIS-Wildlife Services, scott.j.werner@aphis.usda.gov

John L. Cummings

United States Department of Agriculture, Animal and Plant Health Inspection Service, Wildlife Services, National Wildlife Research Center

Shelagh K. Tupper United States Department of Agriculture, Animal and Plant Health Inspection Service, Wildlife Services, National Wildlife Research Center

Jerome C. Hurley United States Department of Agriculture, Animal and Plant Health Inspection Service, Wildlife Services, National Wildlife Research Center

Randal S. Stahl

USDA-APHIS-Wildlife Services, randal.s.stahl@aphis.usda.gov

See next page for additional authors

Follow this and additional works at: https://digitalcommons.unl.edu/icwdm_usdanwrc

Part of the Environmental Sciences Commons

Werner, Scott J.; Cummings, John L.; Tupper, Shelagh K.; Hurley, Jerome C.; Stahl, Randal S.; and Primus, Thomas M., "Caffeine Formulation for Avian Repellency" (2007). USDA National Wildlife Research Center Staff Publications. 727.

https://digitalcommons.unl.edu/icwdm_usdanwrc/727

This Article is brought to you for free and open access by the U.S. Department of Agriculture: Animal and Plant Health Inspection Service at DigitalCommons@University of Nebraska - Lincoln. It has been accepted for inclusion in USDA National Wildlife Research Center - Staff Publications by an authorized administrator of DigitalCommons@University of Nebraska - Lincoln. 


\section{Authors}

Scott J. Werner, John L. Cummings, Shelagh K. Tupper, Jerome C. Hurley, Randal S. Stahl, and Thomas M. Primus 


\title{
Caffeine Formulation for Avian Repellency
}

SCOTT J. WERNER, ${ }^{1}$ United States Department of Agriculture, Animal and Plant Health Inspection Service, Wildlife Services, National Wildife Research Center, 4101 LaPorte Avenue, Fort Collins, CO 80521-2154, USA

JOHN L. CUMMINGS, United States Department of Agriculture, Animal and Plant Health Inspection Service, Wildlife Services, National Wildlife Research Center, 4101 LaPorte Avenue, Fort Collins, CO 80521-2154, USA

SHELAGH K. TUPPER, United States Department of Agriculture, Animal and Plant Health Inspection Service, Wildlife Services, National Wildlife Research Center, 4101 LaPorte Avenue, Fort Collins, CO 80521-2154, USA

JEROME C. HURLEY, United States Department of Agriculture, Animal and Plant Health Inspection Service, Wildlife Services, National Wildife Research Center, 4101 LaPorte Avenue, Fort Collins, CO 80521-2154, USA

RANDAL S. STAHL, United States Department of Agriculture, Animal and Plant Health Inspection Service, Wildlife Services, National Wildlife Research Center, 4101 LaPorte Avenue, Fort Collins, CO 80521-2154, USA

THOMAS M. PRIMUS, United States Department of Agriculture, Animal and Plant Health Inspection Service, Wildlife Services, National Wildlife Research Center, 4101 LaPorte Avenue, Fort Collins, CO 80521-2154, USA

\begin{abstract}
Nonlethal management alternatives are needed to reduce avian depredation of agricultural crops. Caffeine has promise as an effective, economical, and environmentally safe avian repellent, yet formulation improvements are needed for field applications. We included sodium benzoate in subsequent formulations to enhance the solubility of caffeine. Red-winged blackbirds (Agelaius phoeniceus) discriminated between untreated rice and rice treated with $250 \mathrm{ppm}$ or 10,000 ppm caffeine and sodium benzoate in captivity. We observed a positive concentration-response relationship among birds offered rice treated with $250 \mathrm{ppm}, 1,000 \mathrm{ppm}, 2,500 \mathrm{ppm}, 5,000 \mathrm{ppm}, 10,000 \mathrm{ppm}$, or 20,000 ppm caffeine and sodium benzoate. Relative to the pretreatment of the concentration-response test, repellency was $>85 \%$ for rice treated with our 2,500- to 20,000-ppm treatments. We conducted seed germination experiments and associated residue analyses to evaluate the potential phytotoxicity of various caffeine formulations under controlled environmental conditions. The optimized formulation enhanced the solubility of tank mixtures and ameliorated the negative impacts of seed treatments to germination. Our caffeine formulation provides an applicable, nonlethal alternative for managing blackbird impacts to agricultural production. (JOURNAL OF WILDLIFE MANAGEMENT 71(5):1676-1681; 2007)
\end{abstract}

DOI: $10.2193 / 2006-451$

KEY WORDS Agelaius phoeniceus, chemical repellent, depredation, foraging behavior, red-winged blackbird, sodium benzoate, wildlife damage management.

Several bird species cause monetary losses to agricultural production throughout the United States. For example, redwinged blackbirds (Agelaius phoeniceus), common grackles (Quiscalus quiscula), and brown-headed cowbirds (Molothrus ater) caused approximately US $\$ 13.4$ million of damage to United States rice production in 2001 (Cummings et al. 2005). Efforts to manage such damages include the use of repellents and other nonlethal management alternatives (Werner et al. 2005). Chemical repellents can be used as seed treatments to reduce blackbird impacts to newly planted rice or as aerial applications to reduce blackbird consumption of ripening rice.

Schafer et al. (1983) identified caffeine as a potential avian repellent with relatively low toxicity $\left(\mathrm{LD}_{50}=316 \mathrm{mg} / \mathrm{kg}\right.$ for European starlings [Sturnus vulgaris]). Avery and Cummings (2003) found that 2,500 ppm caffeine reduced rice consumption by $76 \%$ among male red-winged blackbirds in captivity. A rice seed treatment of 2,500 ppm caffeine would cost approximately $\$ 3 / \mathrm{ha}$ (at $\$ 8.10 / \mathrm{kg}$; Flavine North America, Inc., Closter, NJ). Blackbirds consumed $<10 \%$ of rice seeds treated with 10,000 ppm caffeine and $>80 \%$ of untreated rice seeds under field conditions in southwestern Louisiana, USA (Avery et al. 2005). Thus, caffeine appeared to be an effective, economical, and environmentally safe avian repellent (Avery et al. 2005). However, formulation

${ }^{1}$ E-mail: Scott.J.Werner@aphis.usda.gov improvements were needed to make caffeine practical for agricultural applications. For example, the low solubility of caffeine in water impeded its mixture during our previous field evaluation (Avery et al. 2005).

We conducted 3 feeding experiments and 2 rice germination trials to develop an optimized formulation of caffeine as an avian repellent for agricultural applications. We included sodium benzoate in our seed treatments to obtain the requisite solubility of caffeine for subsequent field applications. The solubility of caffeine, and caffeine and sodium benzoate combined is approximately $1.5 \mathrm{~g}$ and $83 \mathrm{~g}$ per $100 \mathrm{~mL}$ water, respectively (Gemmill 1958). Our objectives were to 1 ) improve the solubility of caffeine for subsequent field applications, 2) evaluate avian repellency of caffeine and sodium benzoate in captivity, 3) determine the mode of action of caffeine and sodium benzoate as an avian repellent, and 4) optimize caffeine residues and germination of our seed treatments.

\section{STUDY AREA}

We conducted blackbird feeding experiments and rice germination trials at the United States Department of Agriculture's National Wildlife Research Center (NWRC) in Fort Collins, Colorado, USA. We conducted preference and concentration-response tests within an open-sided building at the NWRC outdoor animal research facility. 
The NWRC Analytical Chemistry unit performed caffeine residue analyses associated with rice germination trials.

\section{METHODS}

\section{Preference Testing in Captivity}

We conducted 2 preference tests to determine if red-winged blackbirds could discriminate between untreated rice and rice treated with $250 \mathrm{ppm}$ (test 1) or 10,000 ppm (test 2) caffeine and sodium benzoate. We used a cannon-net (Dill and Thornsberry 1950) to capture 26 adult red-winged blackbirds (M) in November 2004 near Fort Collins, Colorado. We transported all birds to NWRC within 1 hour of capture. We transferred birds to individual cages following group quarantine and holding, and offered them untreated seed rice (ad libitum) in each of 2 food bowls for 3-5 days of acclimation. We provided water ad libitum to all birds throughout preference testing (i.e., acclimation, pretreatment, test).

We offered each bird 2 bowls of untreated rice ( $30 \mathrm{~g}$ each) during each day of the 4-day pretreatment. We collected unconsumed rice (remaining in food bowls) and rice spillage (remaining in trays beneath each bowl) at 0800-0930 hours daily and determined their mass $( \pm 0.1 \mathrm{~g})$. We measured pretreatment and test consumption independently for food bowls located on the north and south sides of each cage. We accounted for changes in the mass of rice independent of rice consumption (e.g., desiccation) by weighing rice offered within a vacant cage throughout testing. We offered each bird 2 bowls of untreated rice (ad libitum) for 3 days between the pretreatment and test.

We offered each bird one bowl of untreated rice and one bowl of rice treated with $250 \mathrm{ppm}(n=6$ birds $)$ or 10,000 ppm ( $n=20$ birds) caffeine and sodium benzoate (1:1) during each day of the 4-day test. We applied treatment solutions $(60 \mathrm{~mL} / \mathrm{kg}$ rice) to $10 \mathrm{~kg}$ certified seed rice (Louisiana State University Rice Research Station, Crowley) using a rotating mixer and household spray equipment. We included $6 \mathrm{~mL}$ Transfilm ${ }^{\circledR}$ (PBI/Gordon, Kansas City, $\mathrm{MO})$ to each treatment solution. We randomized the north-south positioning of treatments within individual cages on the first day and alternated positioning on subsequent days of the test. We offered untreated rice (ad libitum) in 2 bowls for 3 days following the test.

We measured posttest rice consumption during our evaluation of 10,000 ppm caffeine and sodium benzoate to investigate the mode of action of our caffeine formulation. Birds avoid and discontinue sampling food previously associated with secondary repellents (Werner and Clark 2003). If caffeine plus sodium benzoate acted as a postingestive toxin, or secondary repellent, we predicted that posttest consumption of untreated rice would be less than overall pretreatment (i.e., baseline) consumption of untreated rice. We ranked blackbirds based upon average test consumption and assigned them to 1 of 2 posttest treatment groups. We randomly assigned posttest treatments to both groups. We provided 2 bowls of rice treated with $10,000 \mathrm{ppm}$ caffeine and sodium benzoate to birds in group $\mathrm{A}$ ( $n=10$ birds) and 2 bowls of untreated rice to birds in group $\mathrm{B}(n=10)$ during each day of the 4-day posttest.

The dependent measure for preference testing was average rice consumption during the pretreatment, test, and posttest periods. We used the general linear model procedure (SAS Institute, Cary, $\mathrm{NC}$ ) to examine the main effect of testing period (error $=$ period $\times$ subject $)$, and the period-treatment (error $=$ period $\times$ treatment $\times$ subject $)$ and period-daytreatment (residual error) interactions during the pretreatment and test. We separated means of analysis of variance effects $(\alpha=0.05)$ using Tukey's tests. We used descriptive statistics $(\bar{x} \pm \mathrm{SE})$ to summarize rice consumption throughout preference testing. The NWRC Institutional Animal Care and Use Committee approved the capture, care, and use of animals associated with our feeding experiments (Study Protocol QA1127).

\section{Concentration-Response Testing in Captivity}

We conducted a concentration-response test to evaluate repellency associated with varied concentrations of caffeine and sodium benzoate. We captured 48 adult red-winged blackbirds (M) in November 2004 near Fort Collins, Colorado, and transported them to NWRC. We repeated all quarantine, holding, acclimation, and pretreatment procedures (using one food bowl) used during preference testing. We measured daily consumption of untreated rice throughout the 4-day pretreatment.

We ranked blackbirds based upon average pretreatment consumption and assigned them to 1 of 6 treatment groups ( $n=8$ birds/group). We randomly assigned treatments among groups. Treatment groups were used to evaluate repellency associated with $250 \mathrm{ppm}, 1,000 \mathrm{ppm}, 2,500 \mathrm{ppm}$, $5,000 \mathrm{ppm}, 10,000 \mathrm{ppm}$, and 20,000 ppm caffeine and sodium benzoate (1:1). We applied treatment solutions (60 $\mathrm{mL} / \mathrm{kg}$ rice), including $6 \mathrm{~mL}$ Transfilm, to $10 \mathrm{~kg}$ certified seed rice. We measured consumption of treated rice offered in one bowl during each day of the 4-day test.

We hypothesized that repellency would be directly related to the concentration of our caffeine formulation. We predicted that test consumption associated with efficacious treatments would be $<75 \%$ (Schneider 1982) of pretreatment consumption. We analyzed percent repellency (i.e., test day 1 relative to average pretreatment consumption) as a function of treatment concentration using linear regression. We used descriptive statistics $(\bar{x} \pm \mathrm{SE})$ to summarize repellency among treatment groups.

\section{Germination Testing of Rice Seed Treatments}

We conducted 2 controlled trials to determine the effects of caffeine, sodium benzoate, and Transfilm on seed germination. We sealed $450 \mathrm{~g}$ of certified Cocodrie seed rice within each of 6 perforated Ziploc ${ }^{\circledR}$ (S.C. Johnson \& Son, Inc., Racine, WI) bags to initiate trial 1 . We submerged all bags in water for 36 hours. We placed soaked seeds in a cotton bag for 5 hours. We subsequently applied treatment formulations (Table 1) and replaced all seeds within a treatment group in a cotton bag for 24 hours. We then placed 20 treated seeds per treatment in each of 2 petri 
Table 1. Caffeine formulations and associated germination of rice seed treatments that were tested for effectiveness as an avian repellent at the National Wildlife Research Center in Fort Collins, Colorado, USA, April 2005-July 2006.

\begin{tabular}{|c|c|c|c|c|c|}
\hline Treatment & Caffeine (g) & Sodium benzoate (g) & Transfilm (mL) & Water $(\mathrm{mL})$ & Germination (\%) \\
\hline \multirow[t]{6}{*}{ Trial 1 (450 g rice) } & 0.0 & 0.0 & 0 & 15 & 90 \\
\hline & 4.5 & 0.0 & 0 & 15 & 0 \\
\hline & 0.0 & 4.5 & 0 & 15 & 0 \\
\hline & 0.0 & 0.0 & 1 & 15 & 88 \\
\hline & 4.5 & 4.5 & 1 & 15 & 0 \\
\hline & 4.5 & 4.5 & 1 & 20 & 43 \\
\hline \multirow{14}{*}{ Trial 2 (3 kg rice) } & 0.0 & 0.0 & 0 & 200 & 91 \\
\hline & 5.6 & 4.2 & 2 & 200 & 94 \\
\hline & 6.7 & 3.3 & 2 & 200 & 91 \\
\hline & 7.5 & 2.8 & 2 & 200 & 91 \\
\hline & 8.0 & 2.4 & 2 & 200 & 95 \\
\hline & 6.5 & 4.8 & 2 & 233 & 94 \\
\hline & 7.8 & 3.9 & 2 & 233 & 96 \\
\hline & 8.7 & 3.2 & 2 & 233 & 90 \\
\hline & 9.3 & 2.8 & 2 & 233 & 89 \\
\hline & 0.0 & 0.0 & 0 & 267 & 94 \\
\hline & 7.5 & 5.5 & 3 & 267 & 95 \\
\hline & 9.0 & 4.4 & 3 & 267 & 94 \\
\hline & 10.0 & 3.7 & 3 & 267 & 95 \\
\hline & 10.7 & 3.2 & 3 & 267 & 90 \\
\hline
\end{tabular}

dishes (9.5-cm diam) lined with a hydrated $(3.5 \mathrm{~mL}$ deionized water) Kimwipe ${ }^{\circledR}$ (Kimberly-Clark Global Sales, Inc., Roswell, GA). We sealed all dishes with Parafilm ${ }^{\circledR}$ (Pechiney Plastic Packaging, Chicago, IL) and placed them in indirect sunlight for 1 hour. We subsequently placed all dishes in an enclosed dark space (range $=21-23^{\circ} \mathrm{C}$ ) and monitored seed germination each 24 hours. We tallied sprouts $\geq 5 \mathrm{~mm}$ in each dish at the conclusion of trial 1 .

We conducted a second trial to optimize caffeine residues and germination of our seed treatments. We placed $3 \mathrm{~kg}$ of certified Cocodrie seed rice within each of 14 cotton bags. We submerged all bags in water for 36 hours, then drained seeds within bags for 5 hours. We subsequently applied treatment formulations using household spray equipment and a Hobart ${ }^{\circledR}$ mixer (Hobart Manufacturing Company, Troy, $\mathrm{OH}$ ).

We varied the water content and the molar ratio of caffeine and sodium benzoate in trial 2 (Table 1 ). We varied the water contribution by $67 \mathrm{~mL}, 78 \mathrm{~mL}$, and $89 \mathrm{~mL}$ deionized water $/ \mathrm{kg}$ rice. We varied the molar ratio of caffeine and sodium benzoate by 0:0 (control), 1:1, 1.5:1, $2: 1$, and 2.5:1. We included $1 \%$ Transfilm in each formulation. We placed 20 seeds per treatment in each of 4 petri dishes $(9.5-\mathrm{cm}$ diam) lined with a hydrated $(3.5 \mathrm{~mL}$ deionized water) Kimwipe. We subsequently sealed all dishes with Parafilm and placed them in an environmental chamber $\left(25^{\circ} \mathrm{C} ; \pm 0.8^{\circ} \mathrm{C}\right)$. We monitored seed germination each 24 hours until $65 \%$ of control seeds had sprouts $\geq 20 \mathrm{~mm}$ (United States Environmental Protection Agency [USEPA] 1996). We tallied sprouts $\geq 5 \mathrm{~mm}$ in each dish at the conclusion of trial 2 (USEPA 1996).

We collected a $200-\mathrm{g}$ sample of each seed treatment for caffeine residue analyses. Avery et al. (2005) summarized methods used for caffeine residue analyses using reversephase high performance liquid chromatography (HPLC).
We also evaluated the purity of caffeine and sodium benzoate used for formulation treatments using HPLC. We used descriptive statistics to summarize rice germination $(\bar{x} \pm \mathrm{SE}$; trials 1 and 2$)$ and residue data ( $\bar{x}$ ppm [dry]; trial 2).

\section{RESULTS}

\section{Preference Testing in Captivity}

Red-winged blackbirds discriminated between untreated rice and rice treated with $250 \mathrm{ppm}$ caffeine and sodium benzoate during the preference test (Fig. 1A). Although we observed no difference in rice consumption between bowls during the pretreatment (Tukey $P>0.05$ ), all birds consumed less rice treated with $250 \mathrm{ppm}$ caffeine and sodium benzoate than untreated rice $\left(F_{2,10}=39.78, P<\right.$ $0.001)$. On average, birds consumed $10.2( \pm 0.5) \mathrm{g} / \mathrm{bird} /$ day of untreated rice and $1.3( \pm 0.5) \mathrm{g} / \mathrm{bird} /$ day of treated rice during the test (Tukey $P<0.05$ ). We observed no difference in overall rice consumption (i.e., in both bowls) between the pretreatment and test $\left(F_{1,10}=0.00, P=0.984\right)$. We also observed no period-day-treatment interaction $\left(F_{12,60}=0.19, P=0.998\right)$. Thus, blackbirds strongly preferred untreated rice when offered a choice during the 250-ppm caffeine and sodium benzoate test.

Blackbirds also discriminated between untreated rice and rice treated with 10,000 ppm caffeine and sodium benzoate (Fig. 1B). Although we observed no difference in rice consumption between bowls during the pretreatment (Tukey $P>0.05$ ), blackbirds consumed less treated rice than untreated rice during the test $\left(F_{2,36}=465.61, P<\right.$ $0.001)$. On average, birds consumed $11.2( \pm 0.2) \mathrm{g} / \mathrm{bird} /$ day of untreated rice and $0.0( \pm 0.0) \mathrm{g} / \mathrm{bird} /$ day of treated rice during the test (Tukey $P<0.05$ ). We observed no difference in overall rice consumption (i.e., in both bowls) between the pretreatment and test periods $\left(F_{1,36}=0.19, P=\right.$ 


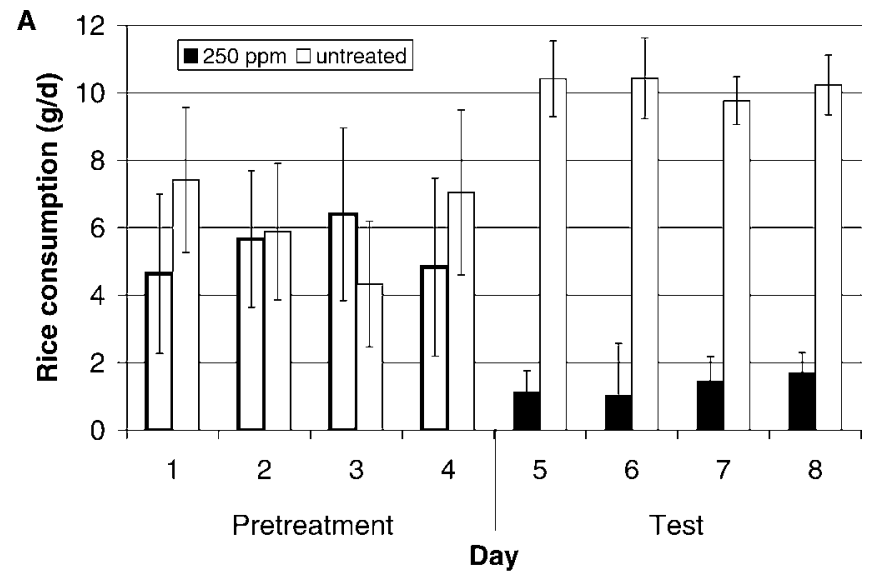

B

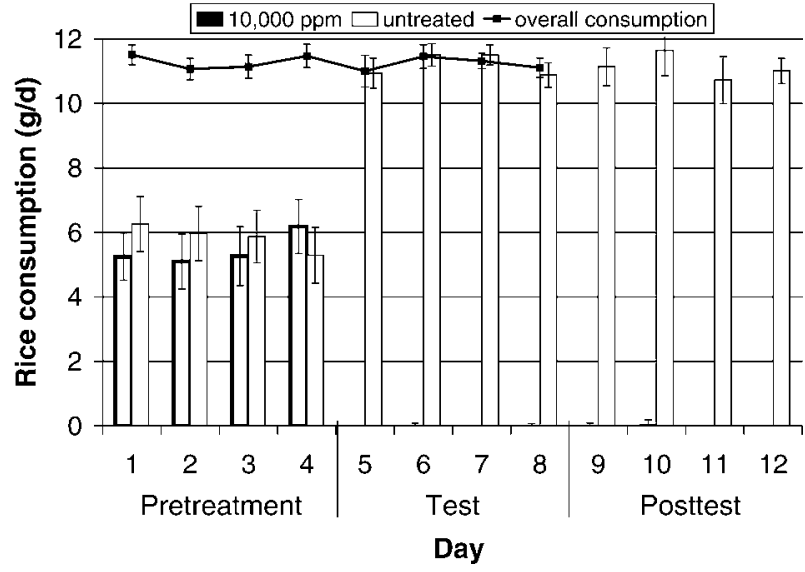

Figure 1. Rice consumption ( $\bar{x} \pm \mathrm{SE}$ ) among red-winged blackbirds offered untreated rice and rice treated with (A) $250 \mathrm{ppm}$ or (B) 10,000 ppm caffeine and sodium benzoate at the National Wildlife Research Center in Fort Collins, Colorado, USA, November 2004. Pretreatment (2 bowls untreated rice) and test data (one bowl treated, one bowl untreated rice) reflect consumption among all birds $(n=6[\mathrm{~A}] ; n=20[\mathrm{~B}])$ from each of 2 bowls. Posttest data (B) reflect overall consumption among birds offered untreated or treated rice in both bowls ( $n=10 \mathrm{birds} /$ group).

0.664). We also observed no period-day-treatment interaction $\left(F_{12,216}=0.29, P=0.990\right)$.

All blackbirds continued to avoid rice treated with 10,000 ppm caffeine and sodium benzoate during the posttest (Fig. 1B). However, blackbirds did not avoid untreated rice subsequent to test exposure. On average, blackbirds consumed $0.0( \pm 0.1) \mathrm{g} / \mathrm{bird} /$ day of treated rice and 11.1 $( \pm 0.3) \mathrm{g} / \mathrm{bird} /$ day of untreated rice during the posttest.

\section{Concentration-Response Testing in Captivity}

Relative to pretreatment rice consumption, red-winged blackbirds consumed $52 \%$ and $88 \%$ less rice treated with 1,000 ppm and 2,500 ppm caffeine and sodium benzoate, respectively (Fig. 2). Blackbirds consumed $<1 \mathrm{~g}$ of rice treated with $5,000 \mathrm{ppm}, 10,000 \mathrm{ppm}$, or $20,000 \mathrm{ppm}$ caffeine and sodium benzoate. Relative to pretreatment consumption, blackbirds exhibited $100 \%$ repellency for rice treated with $\geq 5,000 \mathrm{ppm}$ caffeine and sodium benzoate. We observed a direct concentration-response relationship among tested concentrations of our caffeine formulation

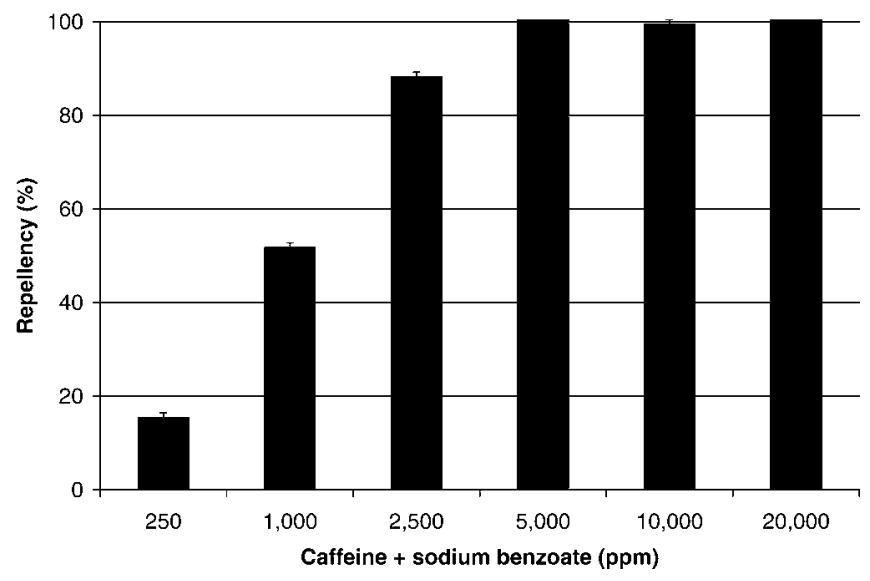

Figure 2. Avian repellency $(\bar{x} \pm \mathrm{SE})$ associated with 6 concentrations of caffeine and sodium benzoate ( $n=8$ red-winged blackbirds/group) at the National Wildlife Research Center in Fort Collins, Colorado, USA, November 2004. Repellency represents test (day 1) consumption relative to average pretreatment rice consumption.

$\left(r^{2}=0.374, P<0.001\right)$. Thus, rice consumption was inversely related to caffeine and sodium benzoate concentration subsequent to the pretreatment.

\section{Germination Testing of Rice Seed Treatments}

We observed $98.5 \%( \pm 0.4 \%)$ and $97.9 \%( \pm 0.5 \%)$ purity of caffeine and sodium benzoate used for treatment formulations, respectively. Approximately $90 \%$ of rice seeds germinated when treated only with water (control seed treatment), and with Transfilm and water (Table 1). We observed no germination among seed treatments of caffeine, sodium benzoate, and $<20 \mathrm{~mL}$ water (Table 1 ). We thus varied the water contribution and molar ratio of caffeine and sodium benzoate among treatments in trial 2. The Louisiana Seed Commission (Louisiana Department of Agriculture and Forestry, Baton Rouge) certified that $80 \%$ germination was expected for the rice seed associated with trial 2 . We observed $>85 \%$ germination among all seed treatments in trial 2 (Table 1).

We observed $<33$ ppm caffeine (HPLC method limit of detection) among our control seed treatments $(200 \mathrm{~mL}$ and $267 \mathrm{~mL}$ deionized water only) in trial 2. We recovered 1,310-2,115 ppm caffeine (1:1 and 2.5:1, respectively) among seeds in the $67-\mathrm{mL} / \mathrm{kg}$ treatment groups (Fig. 3). We observed 1,710-2,305 ppm caffeine (1:1 and 2.5:1) among seeds in the $78-\mathrm{mL} / \mathrm{kg}$ treatments and 1,585-2,535 ppm caffeine (1:1 and 2:1) among seeds in the $89-\mathrm{mL} / \mathrm{kg}$ treatments (Fig. 3). We observed maximum caffeine residues and rice germination with our $89-\mathrm{mL} / \mathrm{kg}$ and $2: 1$ caffeine to sodium benzoate formulation (Fig. 3).

\section{DISCUSSION}

Our formulation of caffeine, sodium benzoate, and Transfilm enhanced the solubility and limited the phytotoxicity of seed treatments. In contrast to other formulations that yielded $>2,000$ ppm caffeine residues (Fig. 3), we observed $95 \%$ germination in each dish associated with our $89-\mathrm{mL}$ water $/ \mathrm{kg}$ and 2:1 caffeine to sodium benzoate formulation. 


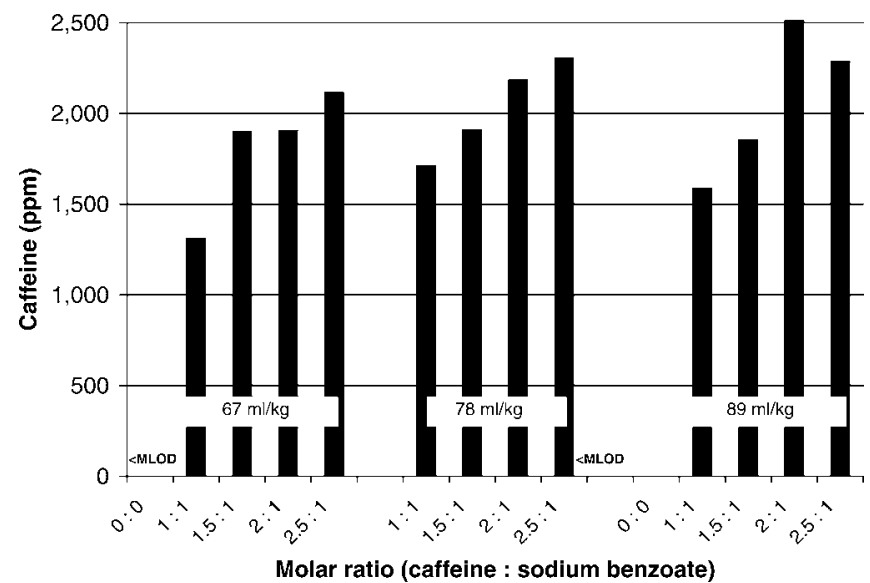

Figure 3. Caffeine residues (ppm [dry]) among varied formulations of caffeine and sodium benzoate that were tested for effectiveness as an avian repellent at the National Wildlife Research Center in Fort Collins, Colorado, USA, July 2006. We varied the molar ratio of caffeine and sodium benzoate by $0: 0$ (control), 1:1, 1.5:1, 2:1, and 2.5:1. We varied water content by $67 \mathrm{~mL}, 78 \mathrm{~mL}$, and $89 \mathrm{~mL}$ deionized water $/ \mathrm{kg}$ rice. The method limit of detection (MLOD) of our residue analyses was $33 \mathrm{ppm}$ caffeine.

The osmotic potential of this solution is $<1 \mathrm{MPa}$ which is near the water stress limit of germinating rice seed (Koller and Hadas 1982). We plan to investigate seed treatments of our formulation as an avian repellent within newly planted rice fields ( $>4 \mathrm{ha})$.

Clark and Shah (1994) observed no repellency (i.e., concentration-response) of 10-5,000 ppm sodium benzoate offered to European starlings in captivity. We observed $24 \%$ and $76 \%$ repellency among red-winged blackbirds during concentration-response testing with $10,000 \mathrm{ppm}$ and 20,000 ppm sodium benzoate, respectively (S. J. Werner, United States Department of Agriculture, unpublished data). Although sodium benzoate is not an effective repellent, it sufficiently increased the solubility of caffeine in our repellent formulations.

Whereas posttest consumption of untreated rice was not less than overall pretreatment consumption, the presence of our treatment (i.e., continuous exposure) was necessary for repellency and aversive conditioning was not apparent. Thus, our caffeine formulation acted as a primary repellent. Primary repellents possess a quality (e.g., unpalatable taste, odor, irritation; Clark 1998) that evokes reflexive withdrawal or escape behavior in an animal (Werner and Clark 2003). We therefore recommend further development of our formulation to enhance the persistence of caffeine under field conditions.

\section{MANAGEMENT IMPLICATIONS}

Agricultural producers have few tools available to reduce bird damages. We recommend a 2:1 molar ratio of caffeine and sodium benzoate, $1 \%$ Transfilm, and $89 \mathrm{~mL}$ water $/ \mathrm{kg}$ as an avian repellent for rice seed. Our optimized caffeine formulation would cost $<\$ 6 / \mathrm{ha}$ as a seed treatment. The United States Food and Drug Administration classified caffeine as Generally Recognized As Safe in 1958. However, additional registration criteria must be satisfied to enable repellent applications of our caffeine formulation. The data requirements for registration include field residue analyses, environmental fate, and acute and chronic toxicology associated with field applications (e.g., potential impacts to crawfish [Procambatus spp.] production). We plan to request an experimental use permit to evaluate our caffeine formulation under extended field conditions.

\section{ACKNOWLEDGMENTS}

We thank J. D. Eisemann, B. A. Kimball, G. M. Linz, and M. E. Tobin for their comments on an earlier version of this manuscript. We also thank the United States Department of Agriculture, Wildlife Services personnel in Louisiana (D. J. LeBlanc, E. A. Wilson) and Missouri, USA (R. W. Byrd) for dedicated assistance with this and ongoing repellents research. We appreciate the National Wildlife Research Center animal care staff who provided daily care throughout our feeding experiments. The Louisiana Rice Research Board, Louisiana State University Rice Research Station, Flavine North America, Inc., and USA Rice Foundation provided financial or logistical support for this study. Corporate collaborations do not imply endorsement by the United States Department of Agriculture.

\section{LITERATURE CITED}

Avery, M. L., and J. L. Cummings. 2003. Chemical repellents for reducing crop damage by blackbirds. Pages 41-48 in G. M. Linz, editor. Proceedings of the management of North American blackbirds symposium. The Wildlife Society Ninth Annual Conference, 27 September 2002, Bismarck, North Dakota, USA.

Avery, M. L., S. J. Werner, J. L. Cummings, J. S. Humphrey, M. P. Milleson, J. C. Carlson, T. M. Primus, and M. J. Goodall. 2005. Caffeine for reducing bird damage to newly seeded rice. Crop Protection 24:651657.

Clark, L. 1998. Review of bird repellents. Proceedings of the Vertebrate Pest Conference 18:330-337.

Clark, L., and P. Shah. 1994. Tests and refinements of a general structureactivity model for avian repellents. Journal of Chemical Ecology 20:321339.

Cummings, J. L., S. A. Shwiff, and S. K. Tupper. 2005. Economic impacts of blackbird damage to the rice industry. Wildlife Damage Management Conference 11:317-322.

Dill, H. H., and W. H. Thornsberry. 1950. A cannon-projected net trap for capturing waterfowl. Journal of Wildlife Management 14:132-137.

Gemmill, C. L. 1958. The xanthines. Pages 299-307 in V. A. Drill, editor. Pharmacology in medicine. McGraw-Hill, New York, New York, USA.

Koller, D., and A. Hadas. 1982. Water relations in the germination of seeds. Pages 401-432 in O. L. Lange, P. S. Nobel, C. B. Osmond, and H. Ziegler, editors. Physiological plant ecology. Volume II. Springer Verlag, New York, New York, USA.

Schafer, E. W., W. A. Bowles, Jr., and J. Hurlbut. 1983. The acute oral toxicity, repellency, and hazard potential of 998 chemicals to one or more species of wild and domestic birds. Archives of Environmental Contamination and Toxicology 12:355-382.

Schneider, B. A. 1982. Pesticide assessment guidelines: subdivision G, product performance. U.S. Environmental Protection Agency, Office of Pesticide and Toxic Substances, Springfield, Virginia, USA.

United States Environmental Protection Agency [USEPA]. 1996. Ecological effects test guidelines. Seed germination/root elongation toxicity test. U.S. Environmental Protection Agency EPA 712-C-96-154, Washington, D.C., USA.

Werner, S. J., and L. Clark. 2003. Understanding blackbird sensory systems and how repellent applications work. Pages 31-40 in G. M. Linz, editor. Proceedings of the management of North American blackbirds 
symposium. The Wildlife Society Ninth Annual Conference, 27 September 2002, Bismarck, North Dakota, USA.

Werner, S. J., H. J. Homan, M. L. Avery, G. M. Linz, E. A. Tillman, A. A. Slowik, R. W. Byrd, T. M. Primus, and M. J. Goodall. 2005. Evaluation of Bird Shield ${ }^{\mathrm{TM}}$ as a blackbird repellent in ripening rice and sunflower fields. Wildlife Society Bulletin 33:251-257.

Associate Editor: Mason. 